\title{
Hemoglobin H disease
}

INSERM

\section{Source}

INSERM. (1999). Orphanet: an online rare disease and orphan drug data base.

Hemoglobin H disease. ORPHA:93616

Hemoglobin $\mathrm{H}(\mathrm{HbH})$ disease is a moderate to severe form of alpha-thalassemia (see this term) characterized by pronounced microcytic hypochromic hemolytic anemia. 